\title{
GEOMETRI FASADE BANGUNAN FRATERAN BUNDA HATI KUDUS DAN SEKOLAH COR JESU KOTA MALANG
}

\author{
Fadlina Rachmatillah ${ }^{1 *}$, Antariksa ${ }^{2}$ \\ Arsitektur Universitas Brawijaya \\ E-mail: *1fadlinarachmatillah@gmail.com, 2antariksa@ub.ac.id
}

\begin{abstract}
Abstrak_ Frateran Bunda Hati Kudus dan komplek Sekolah Cor Jesu yang berada di Kota Malang merupakan bangunan peninggalan masa Hindia Belanda. Lokasi kedua bangunan tersebut berada di koridor Jalan Jaksa Agung Suprapto (Kawasan Tjelaket) yang merupakan kawasan bersejarah di Kota Malang. Pada koridor jalan ini terdapat banyak bangunan dengan langgam arsitektur masa Hindia Belanda. Beberapa bangunan di koridor jalan tersebut masuk dalam daftar bangunan cagar budaya dengan kondisi bangunan yang masih cukup terawat. Dengan berjalannya waktu, dan berkembangnya kebutuhan pengelolaan fungsi bangunan, maka dampaknya adalah perubahan bangunan, terutama pada bagian fasade. Studi ini bertujuan untuk menemukan bentuk geometri, dengan fokus pada kajian proses penyusunan bentuk geometri pada elemen fasade bangunan Frateran Bunda Hati Kudus dan komplek Sekolah Cor Jesu. Metode analisis yang digunakan dalam studi ini adalah deskriptif kualitatif, dengan menggunakan beberapa variabel bentuk geometri yang terdapat pada keseluruhan elemen fasade kedua bangunan tersebut. Hasil studi menunjukkan bahwa elemen fasade bangunan Frateran Bunda Hati Kudus dan komplek Sekolah Cor Jesu memiliki banyak kesamaan pada penggunaan dan proses penyusunan bentuk geometri fasadnya, dengan karakter masing-masing bangunan yang berbeda. Terutama pada bukaan pintu jendela berbentuk persegi panjang pada setiap elemen fasadnya.
\end{abstract}

Kata kunci: Arsitektur; Elemen Fasade; Geometri.

\begin{abstract}
Frateran Bunda Hati Kudus and Cor Jesu School complex in Malang City is a heritage building from the Dutch East Indies era. The location of the two buildings is in the corridor of Jalan Jaksa Agung Suprapto, a historical area in Malang City. On this road corridor there are many buildings with architectural styles from the Dutch East Indies era. Some of these buildings are included in the list of cultural heritage buildings. Over time, and the growing need for management of building functions, the impact is changes in buildings, especially in the facade. This study aims to find geometric shapes, focusing on the study of the process of arranging geometric shapes on the façade elements of the Frateran Bunda Hati Kudus building and the Cor Jesu School complex. The method of analysis used in this study is descriptive qualitative, using several geometric shape variables found in the entire façade of the two buildings. The study results show that the facade of the Frateran Bunda Hati Kudus building and the Cor Jesu School complex has many similarities in the use of the geometry of the facade, with the different characters of each building. Especially on the opening of a rectangular window door on each element of the façade.
\end{abstract}

Keywords: Architecture; Facade Elements; Geometry.

\footnotetext{
${ }^{1}$ Arsitektur Universitas Brawijaya

${ }^{2}$ Arsitektur Universitas Brawijaya
} 


\section{PENDAHULUAN}

Kawasan Tjelaket menjadi jalan penghubung antara Kota Malang dengan Surabaya dan Blitar. Kawasan Tjelaket pada waktu itu menjadi kota perencana pertama (Bouwplan I) dan sempat menjadi pusat pemerintahan Hindia Belanda (Antariksa, 2008). Fungsi bangunan yang didirikan pada saat itu terdiri dari beberapa fungsi bangunan, seperti fasilitas kesehatan, pendidikan, rumah tinggal, serta perdagangan dan jasa. Beberapa bangunan tersebut masih berdiri megah dan terawat sampai saat ini diantaranya, yaitu bangunan Frateran Bunda Hati Kudus dan komplek Sekolah Cor Jesu.

Frateran Bunda Hati Kudus dan komplek Sekolah Cor Jesu memiliki nilai kesejarahan dan berkarakteristik untuk dapat dijadikan sebagai pusaka

kota (urban heritage) di Kota Malang (Mulyadi, 2014). Tampilan fasad kedua bangunan tersebut unik, spesifik dan memiliki khas di antara bangunan di sekitarnya. Hal ini terlihat pada finishing fasade yang mengekspos material dinding batu bata serta terdapat banyak jenis bukaanbukaan seperti pintu, jendela dan ventilasi serta ukuran kedua bangunan yang memberikan kesan megah. Kedua bangunan sekolah hasil rancangan biro arsitek Hulswit, Fermont \& Ed Cuypers dari Batavia (Jakarta) ini apabila dilihat sekilas secara visual hampir memiliki kesamaan khususnya tampilan pada bagian depan bangunannya. Fasade menjadi bagian terpenting dalam proses desain. Dalam proses pembentukan visual fasade terdapat pengolahan bentuk geometri yang telah disesuaikan dengan identitas maupun kebutuhan suatu bangunan. Dalam arsitektur, geometri merupakan alat komunikasi dalam bentuk bangun dan rupa. Elemen-elemen penyusun fasade menurut (Krier, 2001), meliputi atap, dinding, jendela, pintu dan kolom.

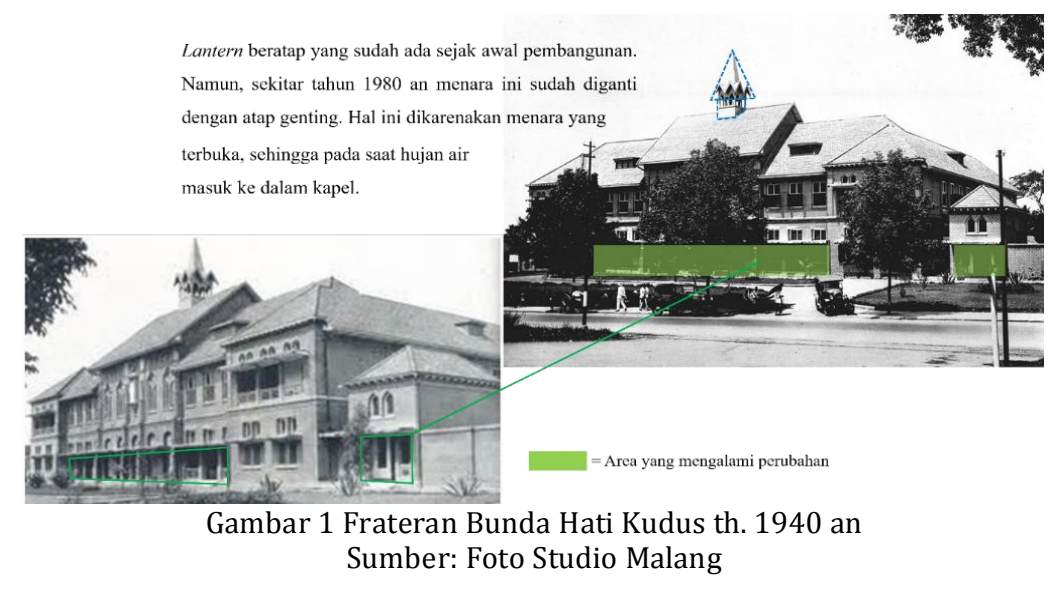




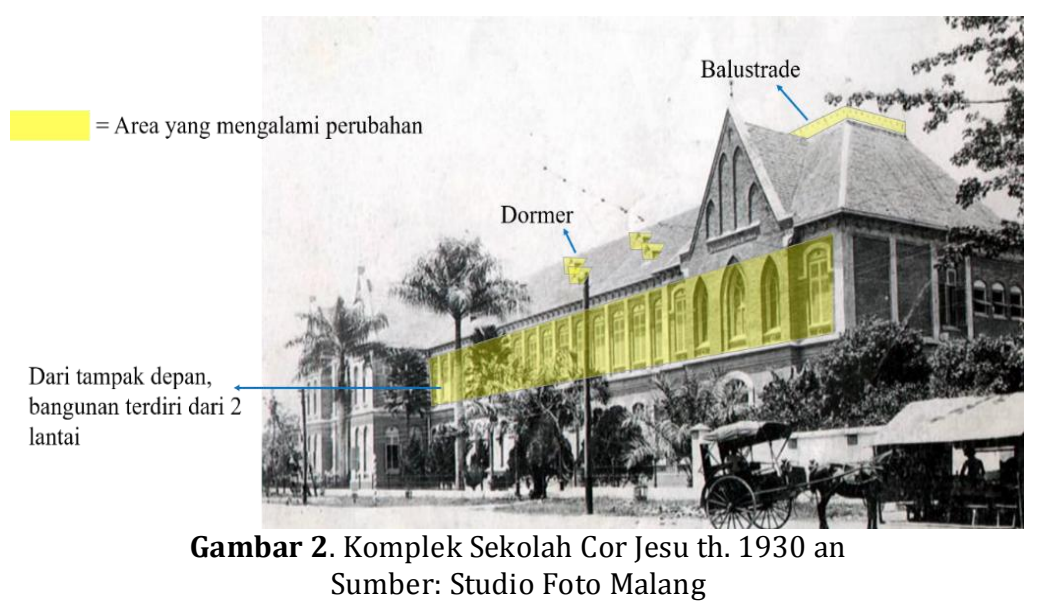

Koridor Jalan Jaksa Agung Suprapto yang terletak pada pusat kota ini kental akan bangunan peninggalan masa Hindia Belanda. Seiring berjalannya waktu dan berkembangnya akan kebutuhan pengelolaan fungsi bangunan, berdampak pada perubahan bangunan terutama pada bagian fasade. Tampilan fasade bangunan Frateran Hati Kudus dan komplek Sekolah Cor Jesu yang unik dan khas ini dapat memberikan karakter visual pada koridor Jalan Jaksa Agung. Tujuan studi ini adalah untuk menemukan bentuk geometri yang berkaitan dengan proses penggunaan dan penyusunan bentuk geometri yang terdapat pada fasade bangunan Frateran Bunda Hati Kudus dan komplek Sekolah Cor Jesu. Sehingga temuan yang diharapkan adalah penggunaan bentuk geometri dari fasade bangunan Frateran Bunda Hati Kudus dan komplek Sekolah Cor Jesu.

\section{METODOLOGI PENELITIAN}

Metode yang digunakan pada studi ini adalah deskriptif kualitatif dengan m endeskripsikan tipologi visual bangunan dan mengumpulkan data dari wawancara, naskah, catatan lapangan dan foto. Metode ini dilakukan dengan menggambarkan kondisi lapangan yang disesuaikan antara objek studi dengan kajian teori. Kemudian ditarik kesimpulan berdasarkan data di lapangan. Objek bangunan dipilih dengan memperhatikan kriteria keaslian dan kelengkapan elemen-elemen penyusun fasade seperti atap, pintu, jendela, dinding dan kolom.

\section{HASIL DAN PEMBAHASAN}

Frateran Bunda Hati Kudus dan komplek Sekolah Cor Jesu merupakan dua dari beberapa bangunan sekolah peninggalan pemerintahan Hindia Belanda. Kedua bangunan sekolah ini masih berdiri kokoh dan terawat serta tetap menjaga keaslian bangunan di tengah era modernisasi yang terjadi saat ini. Geometri fasad digunakan untuk meninjau pada keseluruhan dan elemen-elemen penyusun fasade kedua bangunan tersebut.

\section{A. Geometri fasade bangunan}

Geometri pada keseluruhan fasade bangunan Frateran Bunda Hati Kudus terdiri dari bentuk persegi panjang yang digunakan pada dinding, bentuk segitiga digunakan pada beberapa atap massa bangunan, bentuk lingkaran pada ornamen fasade dan bentuk trapesium digunakan 
pada atap massa utama bangunan (Gambar 3).
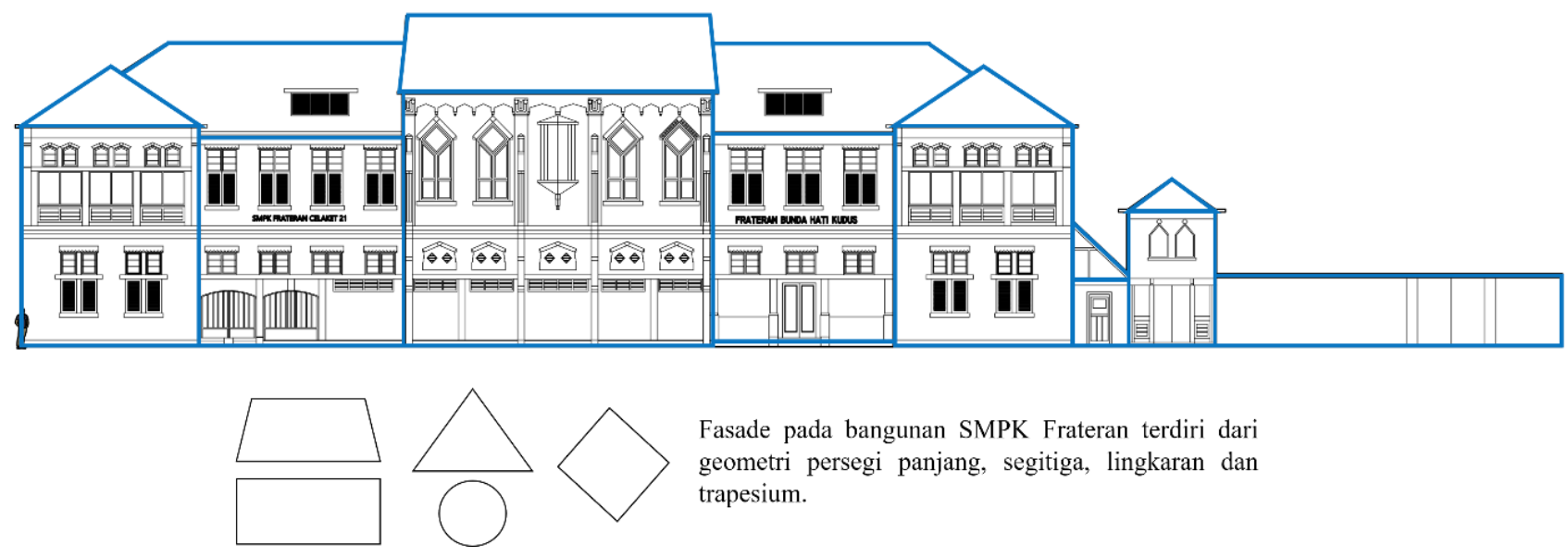

Gambar 3. Tampak depan bangunan Frateran Bunda Hati Kudus.

Geometri pada keseluruhan fasade bangunan komplek Sekolah Cor Jesu terdiri dari bentuk trapesium yang digunakan pada atap, bentuk segitiga pada gevel, bentuk lingkaran digunakan pada ventilasi dan ornamen fasade, serta bentuk persegi panjang digunakan pada dinding (Gambar 4).
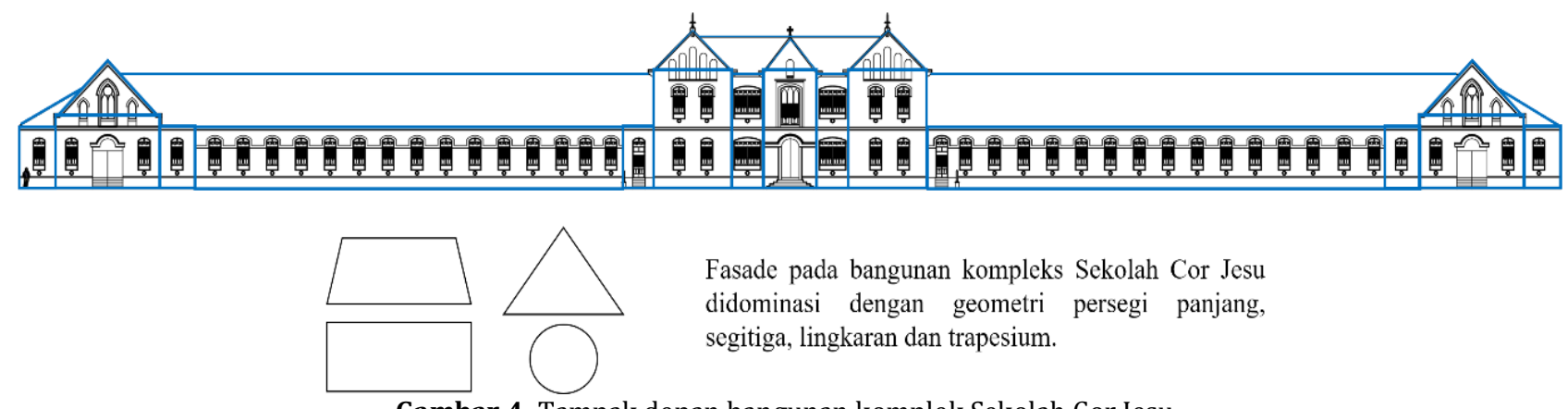

Fasade pada bangunan kompleks Sekolah Cor Jesu didominasi dengan geometri persegi panjang, segitiga, lingkaran dan trapesium.

Gambar 4. Tampak depan bangunan komplek Sekolah Cor Jesu.

\section{B. Geometri pada elemen penyusun fasade bangunan}

Pada studi ini juga dilakukan pengamatan pada bentuk geometri yang terdapat pada elemen-elemen penyusun fasadnya. Elemen penyusun fasade bangunan tersebut diantaranya, adalah atap, dinding, pintu, jendela, ventilasi dan kolom.

1. Atap

Apabila dilihat dari tampak depan bangunan SMPK Frateran Celaket 21 ini memiliki beragam bentuk pada atap. Geometri pada atap bangunan ini menggunakan bentuk trapesium, segitiga, dan persegi panjang pada dormer yang merupakan bagian dari atap (Gambar 5). 


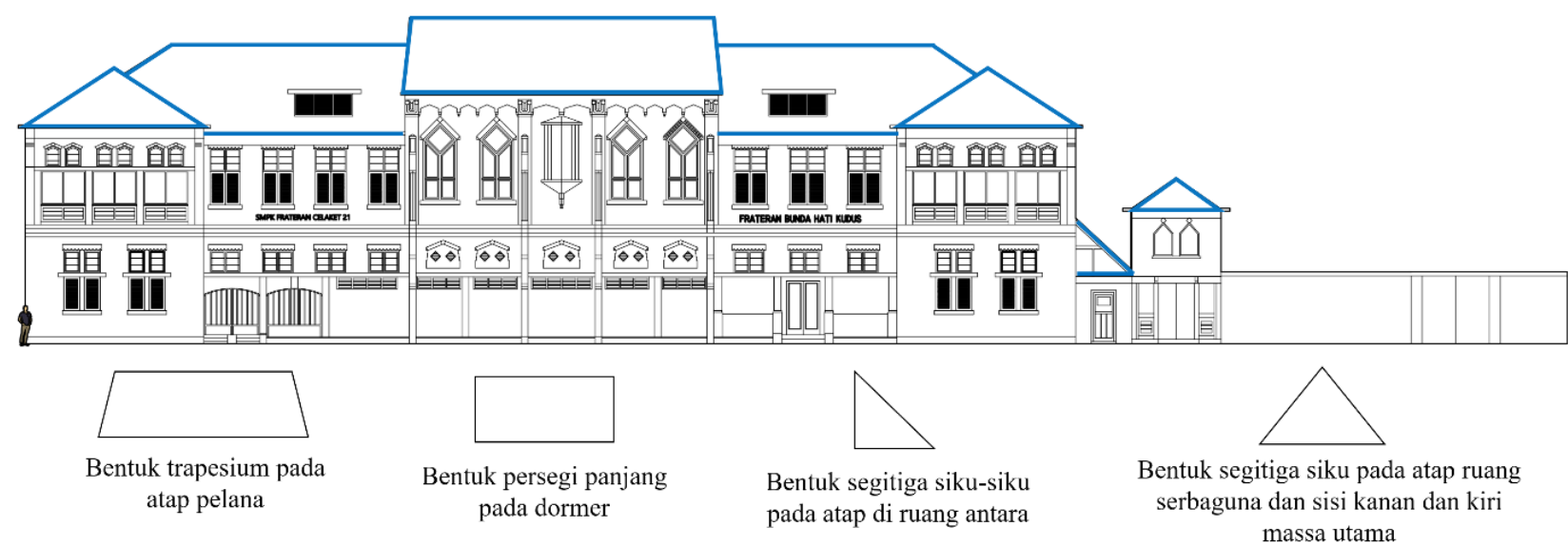

Gambar 5. Geometri atap Frateran Bunda Hati Kudus.

Bentuk geometri pada atap komplek Sekolah Cor Jesu adalah trapesium. Bentuk ini terlihat dari tampak depan bangunan, karena atap yang digunakan pada bangunan adalah atap perisai. Bagian atap bangunan juga dilengkapi dengan gevel yang menggunakan bentuk geometri segitiga (Gambar 6).

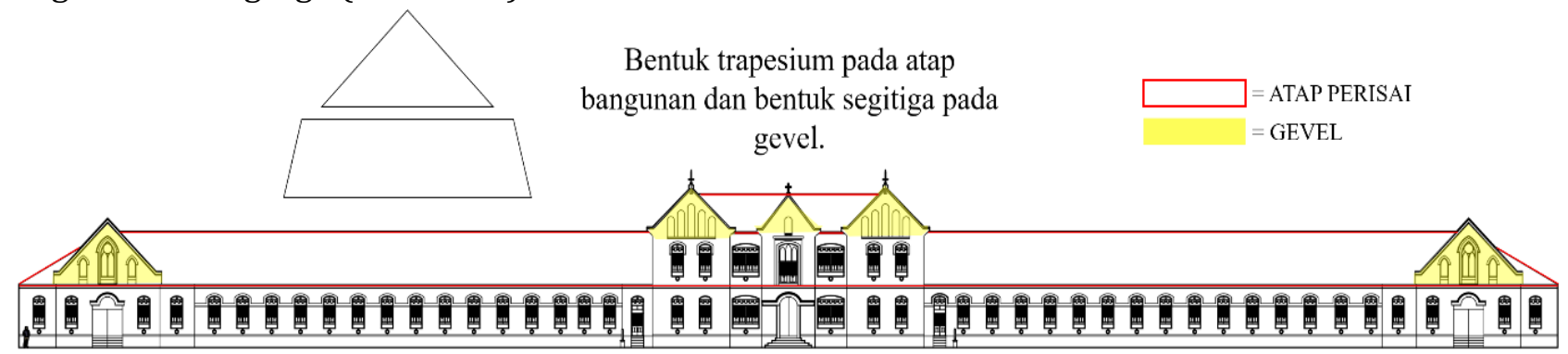

Gambar 6. Geom etri atap komplek Sekolah Cor Jesu.

\section{Dinding}

Bentuk geometri persegi panjang digunakan pada dinding eksterior bangunan Frateran Bunda Hati Kudus dengan tambahan ornamen fasade yang menggunakan bentuk persegi panjang pula. Terdapat dua jenis ornamen pada dinding fasade. Ornament pertama terletak di sepanjang dinding fasade bangunan yang terletak pada bagian pelat lantai dua. Ornament kedua terletak pada bagian ventilasi yang menggunakan bentuk persegi panjang yang distilisasi dengan bentuk segitiga siku-siku (Gambar 7). 


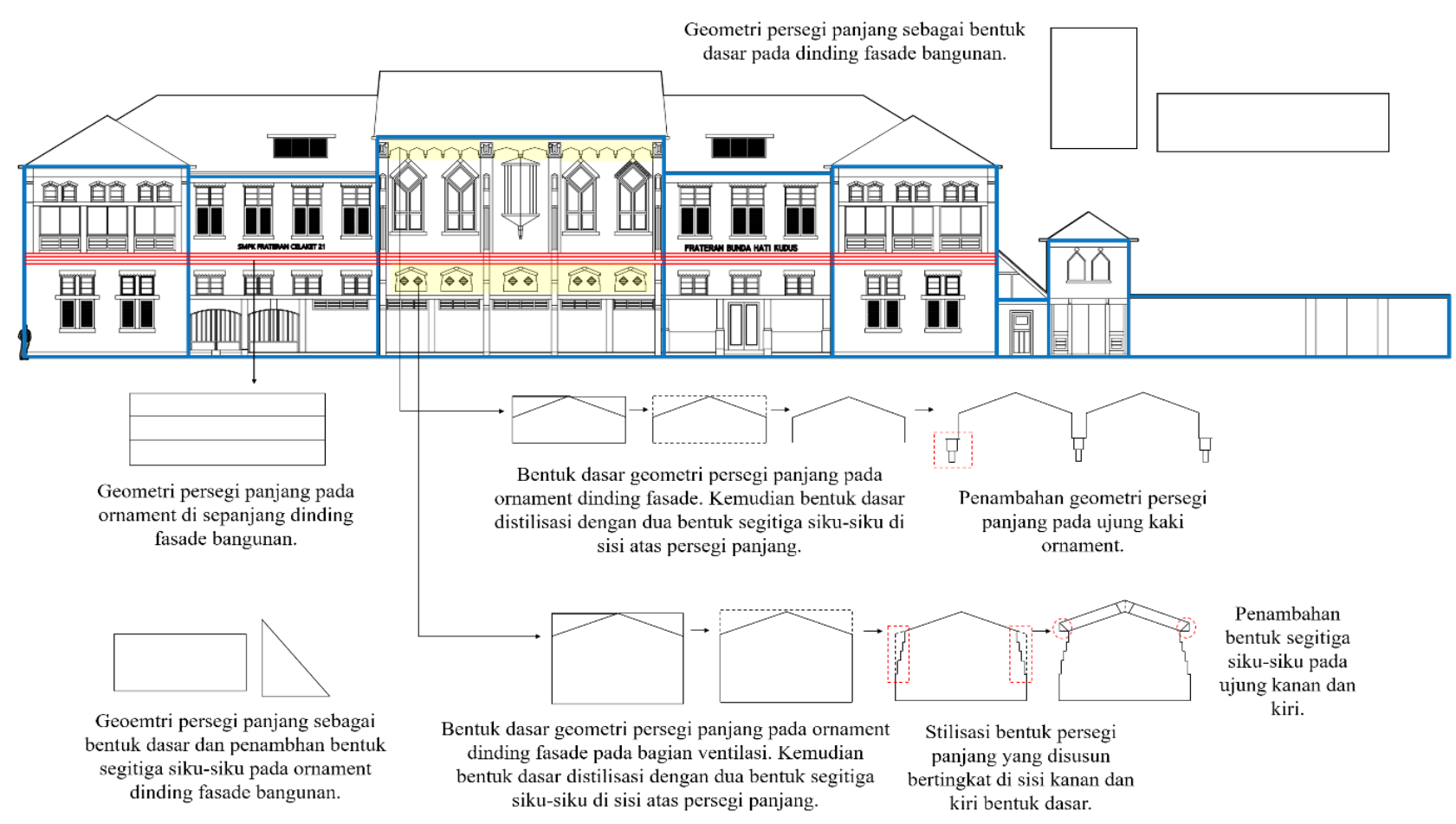

Gambar 7. Geometri dinding fasade Frateran Bunda Hati Kudus.

Dinding pada fasad komplek Sekolah Cor Jesu dibagi menjadi tiga bagian, yaitu bagian dinding kiri, bagian dinding tengah dan bagian dinding kanan. Dinding bagian tengah menggunakan geometri bentuk persegi panjang. Begitu pula pada dinding bagian kanan dan kiri. Kedua bagian dinding ini memiliki kesamaan dari kaki sampai badan bangunan. Geometri pada kedua bagian dinding tersebut adalah bentuk persegi panjang (Gambar 8).

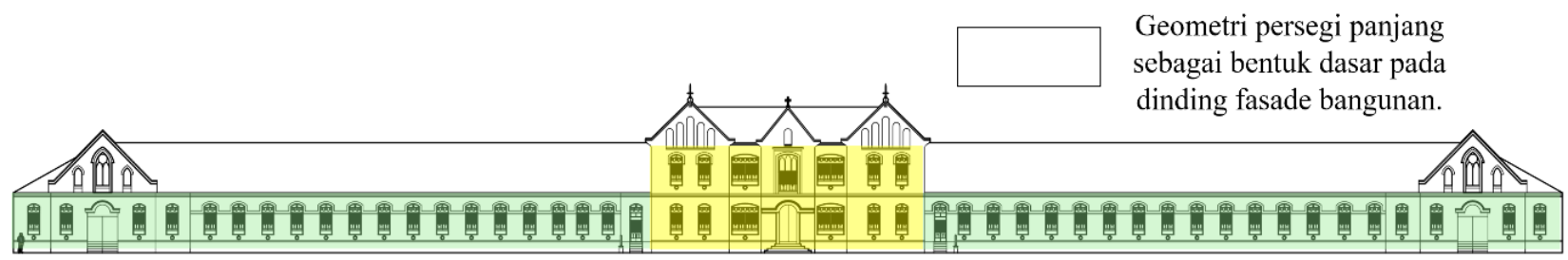

Gambar 8. Geometri dinding fasad komplek Sekolah Cor Jesu.

3. Pintu dan ventilasi

Pintu yang terlihat pada fasade bangunan Frateran Bunda Hati Kudus terdiri dari empat jenis pintu. Pintu masuk menuju sekolah (P1), pintu menuju ruang tamu (P2), pintu menuju ruang antara (P3) dan pintu menuju ruang serbaguna (P4). Keempat jenis pintu tersebut menggunakan bentuk persegi panjang pada daun pintu beserta yang bentuk ornamen yang ada pada masing-masing daun pintu (Gambar 9). 


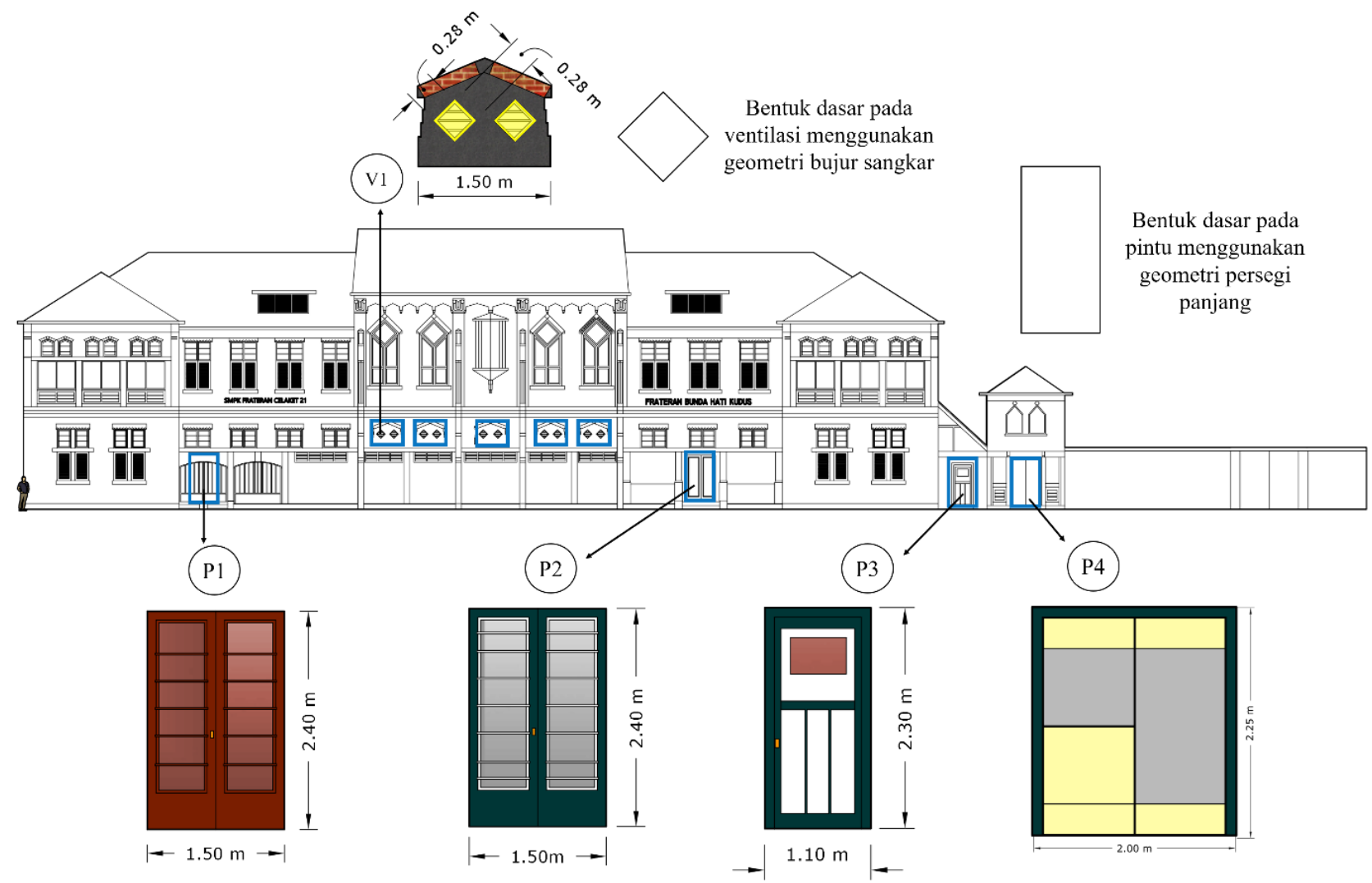

Gambar 9. Geometri elemen penyusun fasade Frateran Bunda Hati Kudus (pintu).

Geometri pada pintu masuk menuju SMPK Cor Jesu, SMAK Cor Jesu dan Yayasan Dhira Bhakti (P1) adalah bentuk persegi panjang. Pada bagian atas pintu dilengkapi dengan jendela mati berbentuk busur. Pada pintu 2 (P2) yang mempunyai akses menuju koridor SMAK Cor Jesu ini juga menggunakan geometri bentuk persegi panjang yang dilengkapi pula dengan ventilasi berbentuk persegi panjang pada bagian atas pintu. Selain bentuk persegi panjang, bentuk lingkaran juga digunakan pada ventilasi (Gambar 10).

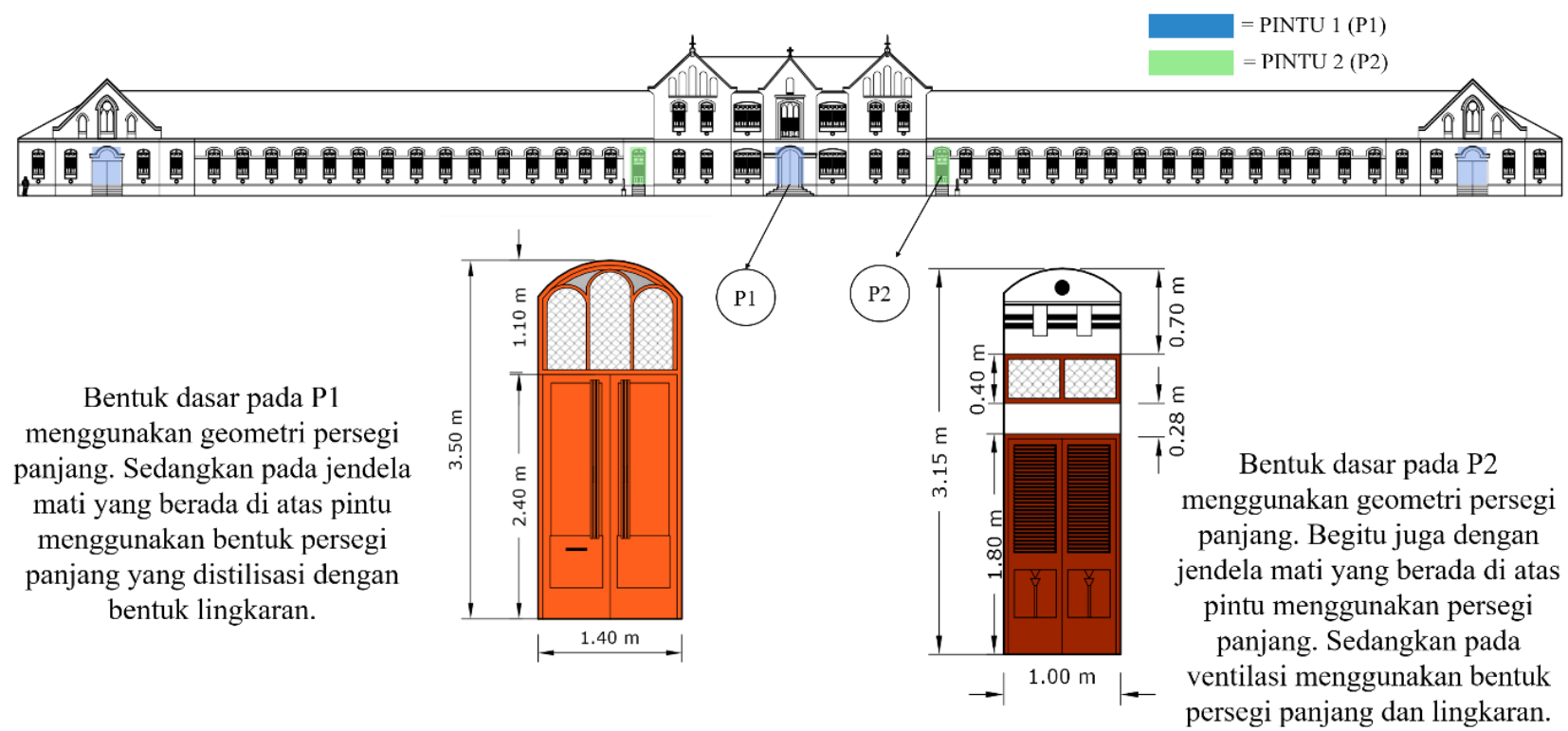

Gambar 10. Geometri elemen penyusun fasad komplek Sekolah Cor Jesu (pintu). 


\section{Jendela}

Terdapat enam jenis jendela pada fasade bangunan. keenam jenis jendela ini didominasi dengan penggunaan bentuk persegi panjang seperti pada J1, J2 dan J5. Geometri persegi panjang juga digunakan pada J3, J4 dan J6. Namun, pada ketiga jenis jendela tersebut ada transformasi bentuk antara persegi panjang dengan segitiga siku-siku, sehingga dihasilkan bentuk jendela yang mengerucut ke atas (Gambar 11).

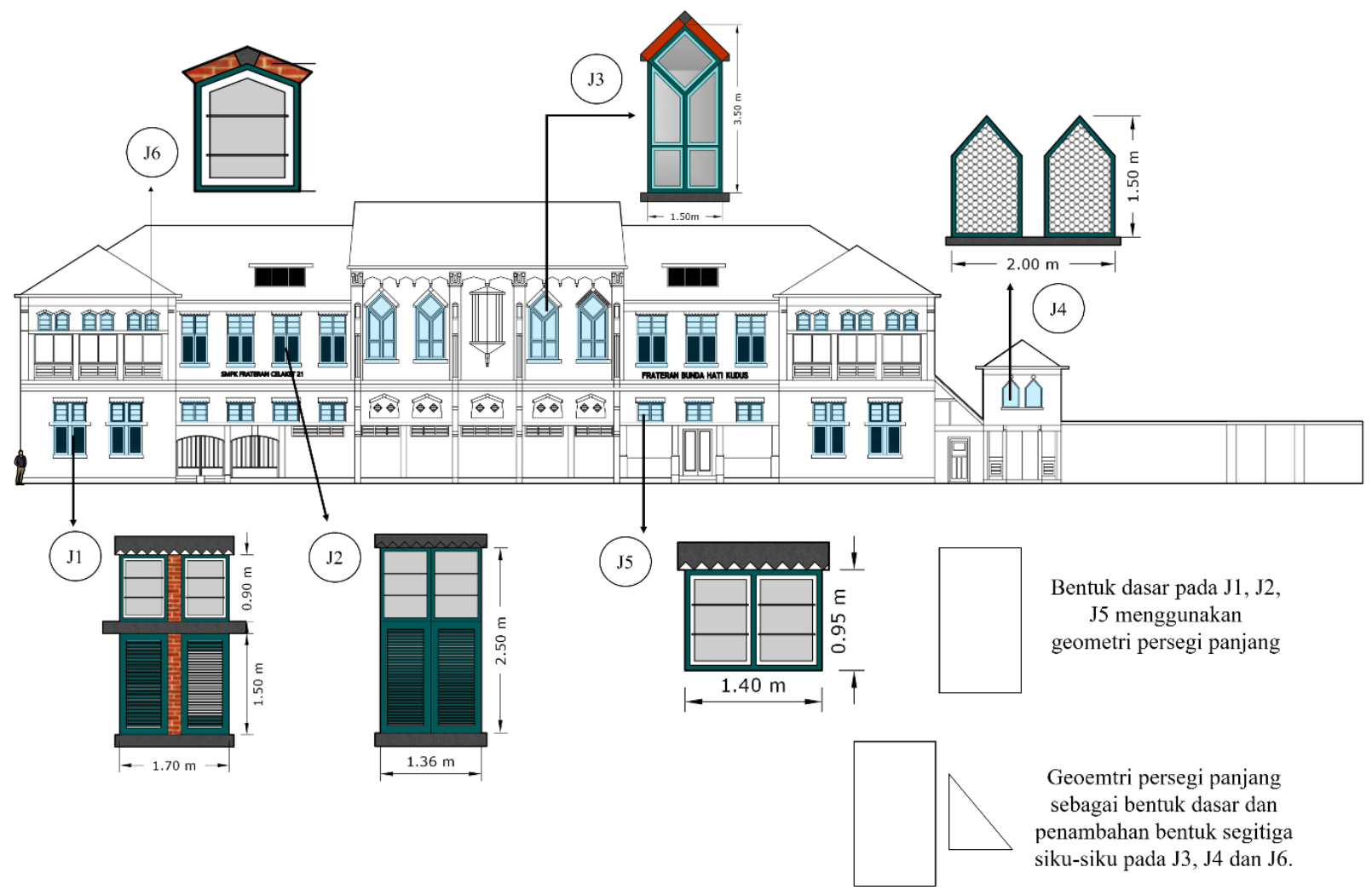

Gambar 11. Geometri elemen penyusun fasad Frateran Bunda Hati Kudus (jendela).

Terdapat tiga jenis jendela pada fasade bangunan komplek Sekolah Cor Jesu. Jendela yang terletak di titik tengah bangunan (J1) menggunakan bentuk persegi pada área daun pintu jendela. Kemudian pada sisi atas J1 yang merupakan jendela mati ini berbentuk busur yang mengerucut ke atas. Selanjutnya, jendela yang berada di sisi kanan dan kiri titik tengah bangunan (J2). Geometri yang digunakan pada J2 adalah bentuk persegi panjang pada daun pintu jendela dan pada ventilasi yang berada di atas jendela. Bentuk lingkaran juga digunakan pada ventilasi yang berada di bawah jendela. Pada fasade bangunan terdapat jenis jendela yang paling dominan, yaitu J3 yang berjajar secara horizontal di sepanjang dinding fasade bangunan. Geometri yang digunakan pada J3 adalah persegi panjang pada daun pintu jendela dan ventilasi yang berada di atas jendela. Bentuk lingkaran juga digunakan pada ventilasi yang berada di atas dan di bawah jendela (Gambar 12). 


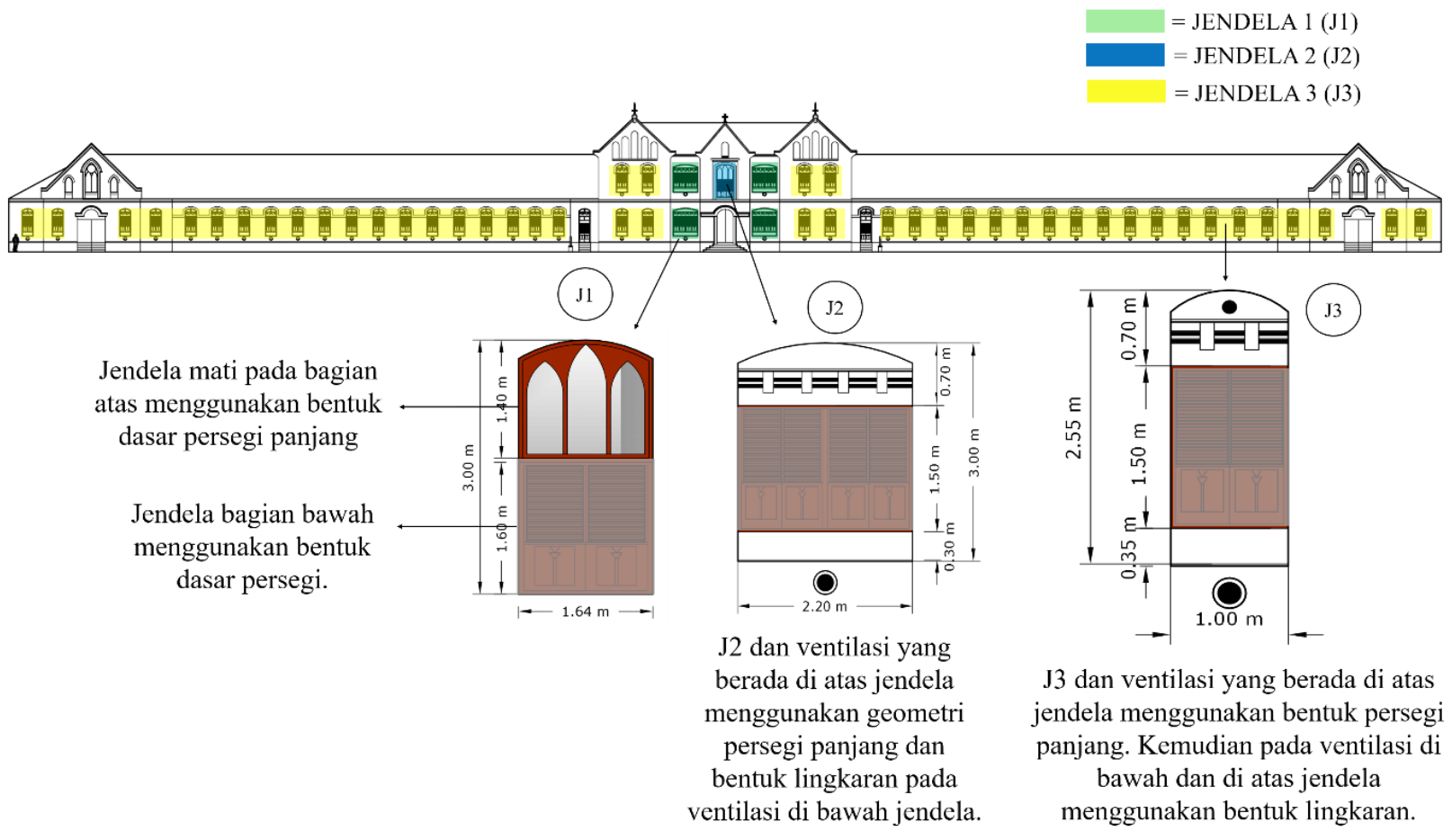

Gambar 12. Geometri elemen penyusun fasad komplek Sekolah Cor Jesu (jendela)

5. Kolom

Pada sisi tengah massa utama bangunan Frateran Bunda Hati Kudus terdapat dua jenis kolom yang berjajar secara horizontal. Geometri yang digunakan pada kolom utama adalah bentuk persegi panjang. Pada sisi atas kolom terdapat yang terbentuk dari perpaduan bentuk persegi panjang dan lingkaran. Selanjutnya kolom jenis kedua ini terletak di antara kolom utama. Kolom jenis kedua ini berjumlah dua buah dan memiliki ukuran yang lebih lebar dari kolom utama. Desain kolom kedua lebih sederhana dan terdiri dari satu bentuk yang digunakan, yaitu persegi panjang (Gambar 13).
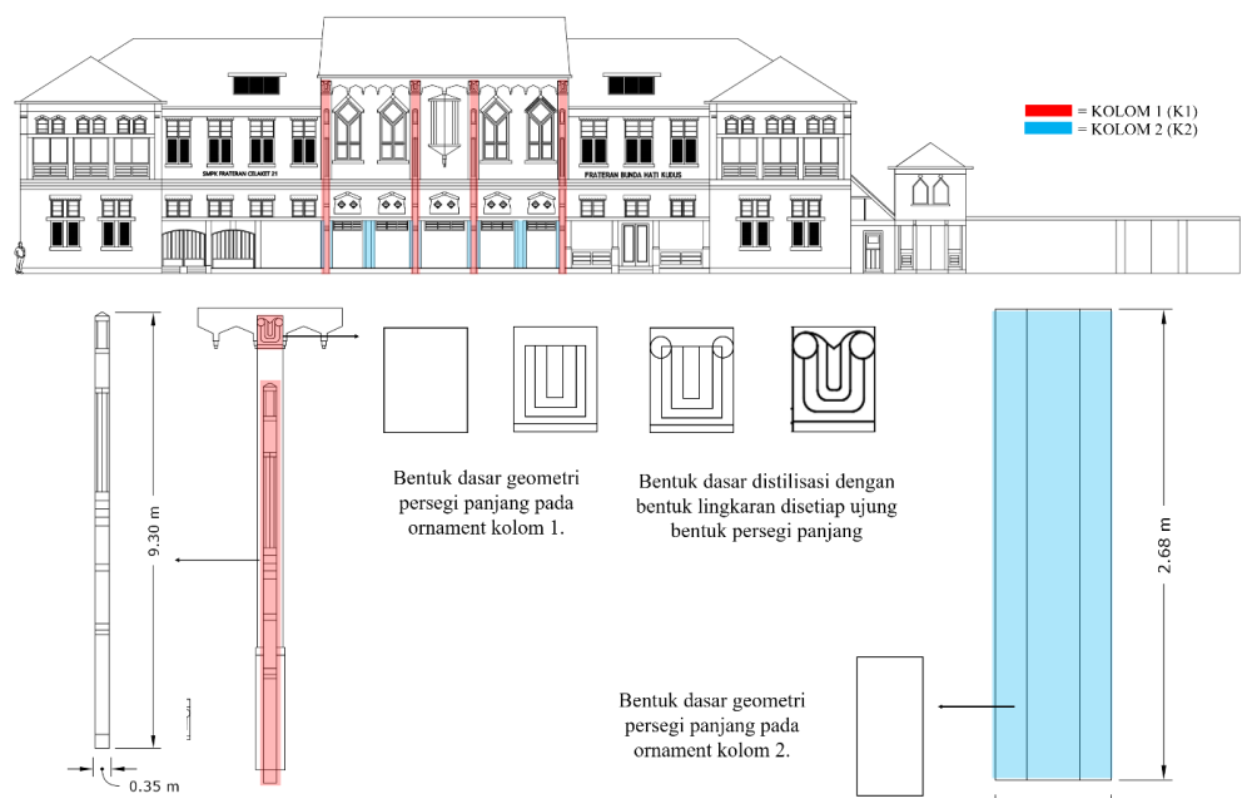

bentuk persegi panjang

ornament kolom 1 Bentuk dasar geometri
persegi panjang pada
ornament kolom 2 .

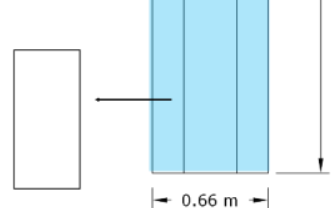

Gambar 13. Geometri Elemen Penyusun Fasad Frateran Bunda Hati Kudus (kolom). 


\section{KESIMPULAN}

Hasil analisis geometri fasade bangunan SMPK Frateran Celaket 21 didominasi penggunaan bentuk geometri persegi panjang, belah ketupat, segitiga dan trapesium. Selanjutnya, yaitu hasil analisis geometri fasad pada komplek Sekolah Cor Jesu menggunakan bentuk lingkaran, persegi panjang, segitiga, dan trapesium. Kedua fasade bangunan tersebut terdapat banyak perulangan dan penggunaan bentuk persegi panjang dan segitiga terutama pada bagian ornamen, jendela dan pintu. Secara keseluruhan kedua bangunan ini memiliki banyak kesamaan dengan karakter visual masing masing bangunan. Fasade bangunan Frateran Bunda Hati Kudus didominasi dengan penggunaan bentuk geometri yang memiliki garis tegas, selanjutnya pada fasade komplek Sekolah Cor Jesu didominasi dengan bentuk lengkungan.

\section{DAFTAR REFERENSI}

Antariksa. 2008. Pelestarian Bangunan Kuno-Bersejarah Kota Malang. https://www.academia.edu/7762320/Pelestarian_BangunanKuno_Bersejarah_di_Kota_Malang. Diunduh pada tanggal 18/03/2020.

Ching, F. D. K. (2015). Arsitektur Bentuk, Ruang, Tatanan, Edisi ketiga. Terjemahan Hanggan Situmorang, Jakarta: Erlangga.

Dinas Kebudayaan dan Pariwisata Kota Malang. (2018). Bangunan Cagar Budaya di Kota Malang Malang: Disbudpar Kota Malang.

Eppi P. Suriwidjaja. (1986). Persepsi Bentuk dan Konsep Arsitektur, Jakarta: Djambatan.

Handayani, Titi. "Identifikasi Karakteristik Façade Bangunan Untuk Pelestarian Kawasan Pusaka di Ketindan, Yogyakarta." Jurnal Arsitektur Komposisi, vol. 9 no. 1 (2011).

Krier, R. (2001). Komposisi Arsitektur, Jakarta: Erlangga.

Mulyadi, L., Sukowiyono, G. (2014). Kajian Bangunan Bersejarah di Kota Malang sebagai Pusaka Kota (Urban Heritage) Pendekatan Persepsi Masyarakat (pp. 1-6). Prosiding Online: Organisasi Temu Ilmiah IPLBI 2013.

Rishnawati, R. Antariksa. Ari, I. R. D. "Pelestarian Koridor Jl. Jaksa Agung Suprapto Kota Malang." Arsitektur eJournal vol. 1 no. 2 (2008).

Samiyah, A. A., Antariksa. Ridjal, M. A. "Geometri Fasade Bangunan Kolonial Belanda di Jalan Veteran Surabaya." Arsitektur e-Journal vol. 10 no. 2 (2017).

Sanyoto, Sadjiman Ebdi. (2009). Nirmana: Elemen-elemen Seni dan Desain. Edisi kedua, Yogyakarta: Jalasutra.

Wardi, Farah A., Antariksa. Suryasari, Noviani. "Geometri Ornamen Pada Fasade Rumah Tinggal Betawi Pinggir." http://arsitektur.studentjournal.ub.ac.id/index.php/jma/article/view/283. Diunduh pada tanggal $23 / 09 / 2019$. 